المجلة الدولية للدراسات القانونية والفقهية المقارنة

بحث رقه 5

المجلد الثاني، العدد الثالث، 214-223

كانون الأول (2021)

\title{
The Israeli violations of the natural resources in Palestine
}

\section{Najah Duqmaq}

Assistant Professor, Faculty of law

Al-Quds University, Palestine

najahduq@yahoo.com
Ahmed Abu Ja'far

Ministry of Justice, Palestine

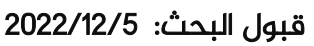

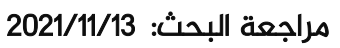

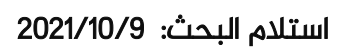




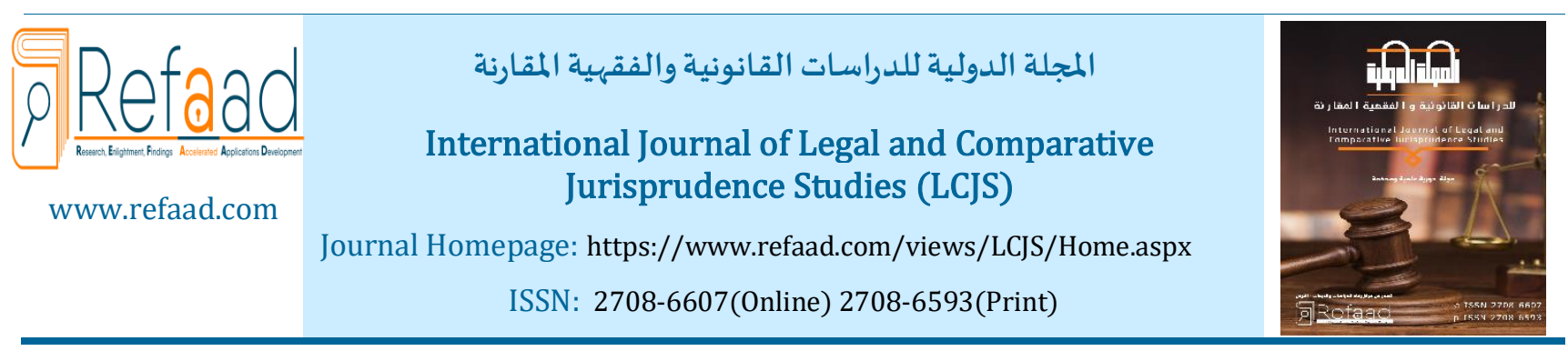

\title{
The Israeli violations of the natural resources in Palestine
}

\author{
Najah Duqmaq \\ Assistant Professor, Faculty of law, Al-Quds University, Palestine \\ najahduq@yahoo.com
}

\author{
Ahmed Abu Ja'far \\ Ministry of Justice, Palestine
}

Received: 9/10/2021 Revised: 13/11/2021 Accepted: 5/12/2022 DOI: https://doi.org/10.31559/LCJS2021.2.3.5

\begin{abstract}
The Israeli private companies deliberately committed various violations against the Palestinian inhabitants and civilian properties by pillaging the natural resources in Palestine. The research sheds light on the need for the Palestinian people to exercise their right over their natural resources and wealth, and the need to stop the violations and practices of Israeli companies that impede the implementation of this right, especially in the Jordan Valley and the Dead Sea, which are major sources of many minerals. Israeli practices violate the Public International Laws by giving the private companies the green light and the necessary declarations and facilities to extract and exploit the natural resources in Palestine. The research gave more attention to these companies' pillage and robbery of the natural resources in Palestine, mainly extracting the minerals in the Dead Sea. The research problem centers on the Israeli flagrant violation for the Public International Law provisions by giving the private companies the green light and the necessary declarations and facilities to extract and exploit the natural resources in Palestine. The research concludes some essential results and recommendations. The most important results are Israel occupied the Palestinian lands for their natural resources and got benefit from them. Israel encouraged and facilitated its civilian population to reside in the Occupied Palestinian Territories. Mining and extracting natural resources in Palestine by Israel for the economic benefit amount to the war crime of pillage, entailing responsibility for Israel and for its officials who commit such types of crimes. The most important recommendations are: Israel must abandon its illegal utilization of the natural resources in Palestine, damaging the Palestinians' properties, building up the Separation Discrimination Wall, transporting the Israeli civilians to the Palestinian Occupied Territories, plundering of the Dead Sea natural resources. The Israeli procedures and activities severely violate mainly the resolutions which have been issued by the UN organs, and Public International Law provisions.
\end{abstract}

Keywords: Public International Law provisions; the Separation Discrimination Wall; International legal responsibility; the natural resources in Palestine.

\section{Introduction}

Since 1967, Israel has seized the Palestinian land to inhabit its settlers and took control over the natural resources. Israel has prevented Palestinians from using and getting benefit from their lands and other natural resources. The Israeli settlers have been utilizing the Palestinian territories causing damage to the Palestinian natural resources.

The Security Council Resolution 2334 in 2016, demanded Israel to stop building up settlements in the Palestinian lands, mainly Jerusalem, and considered the settlements of any nature or purpose in the OPT illegal ${ }^{1}$.

The research talks about Israel's responsibility as an occupying state, and it must shoulder its legal duties when dealing with the natural resources issue. The Israeli occupation is a temporary case, so Israel is considered as a supervisor of these natural resources which are owned and possessed legally by the Palestinians, and Israel is

\footnotetext{
1 The UN official site. The Security Council Resolution 2334. 
forced to administer them in accordance with the rules of usufruct. As a result, Israel is prohibited from exploiting and undermining these natural resources for the favor of its settlers.

The Israeli practices in Palestine can be described as a flagrant violation of its legal obligation for the rules of Public international because Israel deliberately deprives the Palestinians from using and getting benefit from the land and the other natural resources.

\subsection{Statement of the problem}

Israel practices a flagrant violation for the rules of Public international by giving the private companies the green light and the necessary declarations and facilities to mine and utilize the natural resources in Palestine.

The occupier shoulders the legal responsibility for the companies' violations to the Public International Law, besides its responsibility and prosecution before the International Court of Justice for repairing the injury resulting from the exploitation, compensation and preventing these private companies from continuing their robbing of the natural resources.

\subsection{Questions of the study}

- What are the procedures that can be done by the Palestinians to prevent Israel from exploiting the natural resources in its territories?

- What can the State of Palestine do at the international level o to keep the natural resources and get benefit from them?

- How can the Palestinians recruit the member states in the UN to support and adopt the Palestinians attitude to exploit their natural resources, and preventing Israel from practicing its policy?

\subsection{Objectives of the study}

The study aims at achieving the following objectives:

- Knowing the measures that can be adopted by the State of Palestine to limit Israel's exploitation of natural resources.

- Developing practical measures by the State of Palestine to preserve and benefit from its natural resources.

- Shedding the light on Israel's theft of natural resources in Palestine and depriving the Palestinians of benefiting from them.

- Creating an international lobby to support the Palestine's position at the United Nations in accordance with international legitimacy resolutions in order to preserve Palestine's natural resources and prevent Israel's exploitation of these resources.

\subsection{Study approach}

The researchers adopted two approaches which are suitable for this study. The first is the descriptive analytical approach, and the second is the legal applied approach.

\subsection{Research Division}

The study includes two sections:

Topic one: The activity of the private firms and their illegal activities on the Palestinian Land, and the responsibility of Israel in accordance with the provisions of Public International law

1. How can military firms be defined, and what is the nature of the activities they achieve?

2. The nature of the employees who serve in such firms.

3. The Israeli firms that mine and illegally benefit from the natural resources in the Palestine State.

4. What are the ways that Israel adopts to rob the Palestinian land?

5. Environmental Responsibilities of Israel as an occupier in accordance to the provisions of Public International Law.

Topic two: Israel's exploitation of the natural resources in Palestine and its obligations towards the Palestinians

1. The policy of building up settlements in the West Bank, mainly in the occupied Eastern Jerusalem.

2. The apartheid wall and its effect on the Palestinians life.

3. The illegal exploitation and robbing of the Palestinian water resources, and the pillage of the Dead Sea mineral resources.

4. The Palestinian sovereignty over their natural resources and their basic right to self-determination according to the rules of IHL.

5. The Israeli responsibility as an occupier towards the Palestinian occupied lands. 


\section{Topic one: The activity of the private firms and their illegal activities on the Palestinian Land, and the responsibility of Israel in accordance with the provisions of Public International law}

1. How can military firms be defined, and what is the nature of the activities they achieve?

Goddard described the private military companies as:

A civilian company that is devoted to military training, logistic support, communications and intelligence works and military services².

Singer defined private military firms:

Private military companies can be defined as suppliers of professional services that are connected with warfare. Private military companies are considered the corporate evolution of " the soldiers of fortune". In sharp contract of individuals "dogs of war", these are special companies which can produce types of utilities. They can produce certain activities such as, long term planning strategies, necessary intelligence services, logistics support, military equipment, and tactical and essential technical experience ${ }^{3}$.

\section{The nature of the employees who serve in such firms.}

Article 4(a) of Geneva Convention (3), and Article 43 of Additional protocol (1) talked about the armed forces. "The armed forces of a Party to a conflict consist of all organized armed forces, groups and units which are under a command responsible to that Party for the conduct of its subordinates, even if that Party is represented by a government or an authority not recognized by an adverse Party. Such armed forces shall be subject to an internal disciplinary system which, inter alia, shall enforce compliance with the rules of Public International Law applicable in armed conflict"4.

We can conclude from Article 4(a) of Geneva Convention (3) that the employees of the military firms are not really fighters, if these fighters do not fight side by side with the governmental army. Additional Protocol 1 of 1977 considers these employees as really fighters as long as they serve under a responsible leadership. Besides, Article 43 Additional protocol (1) says that "Whenever a Party to a conflict incorporates a paramilitary or armed law enforcement agency into its armed forces it shall so notify the other Parties to the conflict". This means that integration is really an internal matter, so incorporating people like these should be notified by the parties of war. ${ }^{5}$

\section{The Israeli companies that mine and benefit economically from the Palestinian natural resources.}

Since the war ended in 1967, Israel has been paying a remarkable effort, which includes political and military procedures to practice sovereignty rights to have control over the Palestinian natural resources. Here we want to talk about two main companies which are active on the Palestinian territories.

\section{- Mekorot Company}

In the year of 1982, Israel illegally gave the responsibility of the Palestine resources of water in the (OCP) to "Mekorot" private company that deliberately pushed and forced the Palestinian inhabitants to depend completely on the water firm to meet their daily consumption of water. Mekorot provides the Palestinians approximately with most of the water consumed by the Palestinians in the West Bank. Besides, Israel does its best to have the full control over the water resources; Mekorot robs water from the Palestinian share of water to supply copious amounts settlements in the West Bank.

Mekorot cooperates with Israel to achieve "water apartheid", this is a main policy of ethnic cleansing for the Palestinian inhabitants.

Mekorot gets a great benefit from the Israeli policies, in building the settlements and the Apartheid Wall, which violate human rights. Building the settlements and the Apartheid Discrimination Wall is an apparent violation of rights which are adopted by the General Assembly.

The Palestinians have a legal right to have control over their natural resource, especially the right to water, and it is known as an essential right to an adequate standard of living according to Article 11 (1) of the International Covenant on Economic, Social and Cultural Rights. The right of the Palestinians to water is also legally protected and fully guaranteed in accordance with the provisions of the other international treaties and is essential to the enjoyment of the rights to healthy life, enough housing and stuff. The human beings' right to have enough supply of water will enable all the people to enough, healthy, acceptable, share of water for personal and domestic need.

Richard Falk, the Special Rapporteur on the situation of human rights in the Occupied Palestinian Territories, demonstrated in his report the complicity of companies involved in business for international crimes related to

\footnotetext{
2 Dough Brooks, "Messiahs or Mercenaries? The Future of International Private Military Services", International Peacekeeping, Vol. 7, No 4, winter 2000, pp. 134-136.

${ }^{3}$ Singer, P.W,"The Private Military Industry and Iraq. Geneva, November 2004, P.21.

${ }^{4}$ Article 4(a) of Geneva Convention (3), and Article 43 of Additional protocol (1)

5 Gillard, E.C: " Private Military Security Companies: The status of their staff and their obligations under IHL and the responsibilities of states in relation to their operations". Research published in a book (Private Military and Security Companies: Ethics, Policies and Civil Military Relations), Routledge, USA \& Canada, First published, 2009, P. 162.

${ }^{6} \mathrm{Koek}$, E. Water for one People Only. Alhaq Foundation, Ramallah, 2013. P. 17.
} 
the Israeli settlement enterprise, with the target of accountability with respect to the emerging obligations of businesses towards human rights in accordance with the International Law, referring to the decision of a Dutch company (Vitens) for water services to cut its relations with the Israeli company Mekorot, which works to supply all Israeli settlements with water, so that the Dutch company complied with the rules of Public International law ${ }^{7}$. Israel has recently created strategic alliances with the Arab countries that control the water resources ${ }^{8}$, considering this as an acquired right from its view, meeting the needs of its settlers, and making the water issue one of the foundations of peace negotiations based on future ambitions for water resources in the region ${ }^{9}$. Israel aims to take control of the water in the Arab countries that have water resources.

- Ahava Dead Sea Laboratories Ltd

Ahava Company is situated in " MitzpeShalem", a settlement on the Dead Sea Shore in Palestine, and utilizes the natural resources in the West Bank Lands. It is authorized by the Israeli government to mine the Dead Sea mud and offers many products manufactured from the Dead Sea land.

It was established in 1988, and it has the ownership of three global subsidiary firms in Germany, UK and the USA. Ahava's imports were mainly from exports to Europe, the USA, and the rest 40 percent comes from the local sale in the markets of Israel, and tourists who visit and be treated with therapeutic mud from the Dead Sea ${ }^{10}$.

Ahava Ltd. also has a specialized center for tourists and sales promotion in the settlement of 'MitzpeShalem'. Ahava Company gets nearly five times more income than all Jordanian companies together that produce and sell the Dead Sea products.

Ahava receives remarkable tax benefits from the occupying power, like all of the firms located and working in settlements in Palestine. No doubt that the taxes and revenues paid by Ahava to the Israeli Government are not paid to Palestine State.

It is clear that both Mikorot and Ahava firms mine and dig the natural resources in the Palestinian Occupied Territories disregarding the rules of IHL. They work side by side with the international firms from the Western countries to exploit illegally the natural wealth of Palestine. They gain great benefits; on the other hand, Palestine does not get any returns from its natural wealth.

According to the research, these commercial companies should respect the rules of international humanitarian law and human rights law and should not infringe on the rights of Palestinian citizens who are under Israeli occupation, but rather address these negative effects instead of contributing to encouraging them to violate human rights, which damages natural resources and wealth as one of the pillars of the right to self-determination.

\section{What are the ways that Israel adopts to rob the Palestinians land?}

Israel has used various ways to rob the Palestinian lands. It seized the Palestinian land for the Israeli troop's purposes, announcing to the public that the seized lands are dedicated for the Israeli troops training or as wildlife reserves ${ }^{11}$.

The complicity of companies contributes to committing serious violations of the rights of Palestinian citizens, which highlights the unequal aspect in the distribution of water, the exploitation of the resources of the occupied land, the construction of the Discrimination Wall, and continuous Israeli oppression that coincides with the process of displacement of Palestinians to bring Jewish immigrants in their place through the continuous settlement activity in building settlements to transfer the Israeli civilians to the Palestinian Territories ${ }^{12}$.

Israel has adopted various means to confiscate the Palestinian lands, through Israeli laws and military orders under several pretexts to seize Palestinian land, including "state lands", deserted lands, "closed military areas" in order to achieve its political goals in implementation of the Israeli Alon Plan of 1967 with regard to the annexation of lands from the West Bank, the confiscation of lands along the Jordan River and the Dead Sea, the control of water in aquifers, and the construction of settlements to ensure their security on the borders of the eastern front 13 .

5. Environmental Responsibilities of Israel as an occupier according to the Public International provisions

Israel has been occupying the Palestinian Territories for over five decades, so its occupation is considered a prolonged according to the rules of public international law.

\footnotetext{
7 United Nations Human Rights Council, 25th Session, Report of the Special Rapporteur on the situation of human rights in the Palestinian territories occupied since 1967, Richard Falk, January 13, 2014. Index number: A/HRC/25/67, item, 39, 40, 41, p. 16.

8Marakami, Masahiro, (1995): Managing Water for Peace in the Middle East, Alternative Strategies. Tokyo: UN University Press. P. 61.

${ }^{9}$ Mansoor, Suliemam: The Zionist Policy towards Arab Water.The faculty of Law and Political Science, the second issue, Sousa, Tunisia, 2014, P.21.

${ }^{10}$ Nicoleti, C. Pillage of the Dead Sea, Alhaq Foundation, Ramallah, 2012. PP.21-22.

${ }^{11}$ West Bank Settlements: Facts and Figures 2009. http://Peace now.org.il.org. /node/297.

${ }^{12}$ Corporate Complicity in Violations of International Law in Palestine, Palestinian Resource Center for Residency and Refugee Rights, Badil, April 2015, p. 5.

${ }^{13}$ Israeli Policies in Areas Classified "C" Obstacles to Development and the Intervention of the Palestinian Government in Confronting them, Independent Commission for Human Rights, Court of Justice, Report Series “85) 2016, pp. 9-10 
- Israel's Environmental Responsibilities as an Occupying Power during a military Occupation

This expression is usually known as a main part of International Humanitarian Law of armed conflicts. It is ruled by a group of IHL criteria of armed conflicts due to the territories that it captures, its inhabitants, and normally the natural environment.

The law of the belligerent or military occupation is centered on the prosperity and healthy life of the inhabitants, the possession of their lands, and the ways they earn their living. Taking care of the natural environment has always been an essential interest of the modern world.

The Israeli State has not signed Protocol 1 of 1977, as a result, it does not abide by it. Anyway, the relevant articles of Additional Protocol 1, mainly articles 35 and 55, are considered essential parts of customary international law. ${ }^{14}$

- Keeping objects necessary to the life of Civilian inhabitants

Article 54 of additional protocol 1 states that states at war must protect and keep objects necessary to the life and survival of the civilian inhabitants. This contains "foodstuffs, crops, livestock, and drinking water installations". It is forbidden to being attacked because they are essential needs for the inhabitants in the occupied territories. 15

- Protection and keeping the natural environment in the occupied territories

Article 35(3) of the Additional Protocol 1 provides the "basic rules" and at paragraph 3 states that "it is prohibited to employ methods or means of warfare which are intended, or may be expected, to cause widespread, long-term and severe damage to the natural environment" 16.

The Israeli occupation is really a prolonged one. As a result, such activities are not connected with the means of warfare, but really connected with the systematic destruction of the environment which eventually cause the widespread, long-term, and destruction to the environment.

\section{Topic two: Israel's exploitation of the natural resources in Palestine and its obligations towards the Palestinians}

\section{The policy of building up settlements in the West Bank, mainly in the occupied eastern Jerusalem}

Over the last 50 years, Israel has followed a systematic policy to take control and plunder the natural resources in Palestine. It has followed various methods to achieve its targets. The Likud party, besides the other parties in Israel, considers the Palestinian territories parts of "Great Israel", they are described as lands "C". There are certain provisions that prevent Israel as an occupier to take control over the land and plunder the natural resources in the territories that it occupies. Article one of the International Covenant on Civil and Political Rights states that: "All people may, for their own ends, freely dispose of their natural wealth and resources without prejudice to any obligations arising out of international economic co-operation, based upon the principle of mutual benefit, and Public International Law. In no case may people be deprived of its own means of subsistence". The International Declaration of Human Rights 1948, in article 17 says:

"Everyone has the right to own things or share them. Nobody should take our things from us without a good reason". Israel illegally violated the provisions of International Humanitarian Law by building up the settlements. It has transferred about 560,000 Jewish civilians into the Palestinian lands ${ }^{17}$. This action is not accepted, and it is normally prohibited in accordance with the provisions of the Public International Law in general.

Article 49, (6) of the Fourth Geneva Convention explicitly states that, "the occupying power shall not deport or transfer parts of its own civilian population in the territories that it occupies". The Security Council Resolution 446 (1979) and 465 (1980) explicitly condemned building up the settlements, and considered such action illegal, moreover, the International Court of Justice in its advisory opinion in 2004 considered "establishing the settlements, including East Jerusalem, are unlawful and obstacles towards achieving peace, and this opinion is very essential during the final negotiations between the Palestinians and Israelis.

Therefore, the Israeli settlements are basically a major barrier which prevents the Palestinians from achieving their dream in living in their own independent state beside Israel. The Israeli settlements affected the Palestinians life since they are built on the fertile agricultural land which the Palestinians depend on for their lives. Settlers use and consume more and more water; on the other hand, Palestinians do not consume half of the settlers' amount. In addition to what has been mentioned, the wastewater that comes from the Israeli settlements is discharged in a programmed way into the Palestinian near valleys without any treatment. This action caused a lot of damage for the Palestinian lands, and spread the diseases in the villages and towns they live in.

The Palestinians have the legal right to get benefit from the natural resources in their state. The General Assembly Resolution 66/225 of 29 March 2012 asserted that Palestinians can exercise their normal rights over the natural

${ }^{14}$ Takahanshi, Y: The Law of Occupation, Martinus Publisher, Boston 2009. P. 106.

${ }^{15}$ Lucia, V: Enviromental Injustice in Occupied Palestinian Trritories, Alhaq Foundation, Ramallah215, P.39.

16. Article 35(3) of the Additional Protocol 1

17 Article one of the International Covenant on Civil and Political Rights. article 17 of the International Declaration of Human Rights 1948 
resources they possess, and asked the occupier state to abandon the mining, exploitation, damage, and endangerment of those natural resources ${ }^{18}$.

\section{The Apartheid Wall and its effect on the Palestinians life}

Israel constructed the Apartheid Wall in June 2002. The main target of the wall is to rob the Palestinian lands to seize more of the Palestinian land and to enlarge the Jewish settlements in the occupied Palestinian Territories. The wall's height is 8 meters and is more than 800 kilometers long. It crosses the heart of the occupied West Bank so as to rob more and more lands. ${ }^{19}$

\section{- The Apartheid Wall and the IHL rules}

Constructing the Apartheid Wall is a great violation to the rules of IHL. The successive resolution adopted by the UN explicitly assured that the Palestinian lands belong to the Palestinian people.

Article 53 of the Fourth Geneva Convention says that "Any destruction by the occupying Power of real or personal property belonging individually or collectively to private persons, or to the state, or to other public authorities, or to social or cooperative organizations, is prohibited, except where such destruction is rendered absolutely necessary by military operations.

So, Israel is now damaging the fertile land, which is dedicated for agriculture, and removing the Palestinian villages. It violates the provisions of IHL, basically articles 33,147,153 which really provide certain and safe protection for the Palestinians under the Israeli Occupation. The provisions of IHL severely prevent Israel from damaging the civilians' crops which they depend on for their living20.

\section{- The Advisory Opinion of the ICJ ON the Apartheid Wall}

The Discrimination Wall is constructed on the Palestinian fertile agricultural lands targeted to surround and encompass many settlements that are besieging the Palestinian lands.

The advisory opinion of the International Court of Justice stated that the "Construction of the wall on the Palestinian Territories was contrary to International Law for many reasons":

1. The discrimination Wall prevents the Palestinians illegally from practicing their right to selfdetermination.

2. It creates a "fait accompli" on the Palestinian lands that could become a permanent situation, putting into consideration that Israeli assured that its action does not amount to annexation to the Palestinian territories and is of a temporary procedure.

3. The route of the discrimination Wall reinforces the status of the Israel's unlawful settlements.

4. The wall establishment caused a lot of destruction or requisition of the Palestinian.

The ICJ asked Israel to stop building up the wall immediately, to demolish the built parts and compensate the Palestinians for the loss and injury caused by Israel21.

Finally, we can say that the wall caused a great damage to the Palestinians: The amount of water dedicated for drinking is not enough. The Palestinians have been systematically prevented from using and cultivating their land which, that normally provides them with the necessary crops for their life.

3. The illegal exploitation and robbing of the Palestinian underground water resources, and the pillage of the Dead Sea mineral resources

- The Israeli mining and illegally exploitation of the Palestinian water

The Palestinians suffered severely from the lack of clean, healthy and safe water. Israel deliberately deprived the Palestinians of the necessary water resources for their normal life.

Israel illegally exercises control over the water resources in Palestine. Israel's water supply system and denial to access to their water resources are an apparent policy to its colonial and discrimination policy.

The annexation policy which Israel depends on in the Palestinian territories facilitates the integration of the Palestinian lands into the Israeli State. Israeli settlers consume more and more water at the expense of Palestinians' share of their own water 22

\section{- The Israeli robbery of the Dead Sea water resources}

Since the beginning of the Israeli occupation of 1967, Israel has been exploiting and mining most of the Dead Sea resources, the land and the water. It considered this area as "state land". The government of Israel has seized the Palestinian parts of the Dead Sea land which are devoted for the Palestinians, so as to deprive them from getting any potential benefit from the unique and rich natural resources in the Dead Sea.

Israel does not have the right to deplete the resources which are found in the Dead Sea area, but it can use and utilize these natural resources to supply the specific military needs. Israel is a temporary occupier; so it

\footnotetext{
${ }^{18}$ Article 49, (6) of the Fourth Geneva Convention. The General Assembly Resolution 66/225 of 29 March 2012.

${ }^{19}$ Article 53 of the Fourth Geneva Convention. Yaqin, S: The Israeli Aparthied Wall, Arab center Studies, Beirut, 2015. P.13.

${ }^{20}$ Alqasem, A.: The Wall of Ideology, Dar Alfikr, Amman, 2009.P.88.

${ }^{21} \mathrm{http}$ ://www.icj-cij.org/docket/index.php?. The advisory Opinion of the ICJ.

${ }^{22}$ Caffery,S. The Law of International Watercourses. Oxford Univesity Press, New York, 2007.P.308.
} 
cannot deplete the natural resources in a way that put an end these resources use the returns for its colonial expansion.

Israel's actions in the Dead Sea area are considered a grave violation of the humanitarian and human rights law rules, and its duty as an occupier state for the PT. Israel economically benefits from the exploitation of the occupied territories' natural resources on the account of the Palestinians. As a result, the Israeli procedures could amount to war crime of pillage which are not permitted and allowed in accordance to the public international law provisions ${ }^{23}$.

The researchers suggest that the government of Israel must stop exploiting the natural resources in the Occupied Palestinian Territories, as the occupying power, especially the Dead Sea water resources and abide by the rules of international humanitarian law regarding the applicability of the Fourth Geneva Convention on Civilian Population of 1949 to the Palestinian land.

4. The Palestinians sovereignty over their natural resources and their basic right to self-determination in accordance with the provisions of IHL

The Israeli policy of exercising sovereign rights over the Palestine natural resources aimed at dispossessing these natural resources from the Palestinians, and a step towards possessing and capturing them.

Practicing the Palestinians right to self-determination is considered an essential principle according to the rules of Public International Law. It is a guarantee for the Palestinians to practice their legal rights on their land. The above mentioned right means that all people live on the earth have this right freely, without any kind of interference from the occupier, to pursue their economic, social, and educational programs, all states which are members of the UN are obliged to fully respect this right achieving the United Nations Charter.

As a result, the obligation to guarantee the right to self-determination is an obligation fall upon all the states which are members in the modern world.

Since the year 1948, the United Nations Organs, mainly the General Assembly and the Security Council, have asserted the Palestinians right to self-determination, and condemning the Israeli Policy in possessing the Palestinians natural resources, and the grave violations of human rights in Palestine.

The General Assembly connected this right with the main principles of customary international law concerning the full control for the Palestinians over their natural resources, considering that it is an essential component in practicing the Palestinians their right to self-determination in their independent state 24 .

The principle of permanent sovereignty for the Palestinians over their natural resources prevents Israel as an occupier from exploiting and mining the Palestinians' natural resources. It is a necessary factor and inherent component of sovereignty, which enables the occupied Palestinians to freely dispose of their natural resources. Naturally, this contains the right to use, keep and administer the natural resources in order to encourage the natural evolution in the State of Palestine.

The right of the Palestinians to permanent sovereignty over their natural resources becomes relevant when taking into consideration the prolonged occupation because Israel's temporary right to use and consume the fruits deriving from the occupied territories' property cannot last for an indefinite period. No doubt that the Israeli occupation is of a temporary nature. This concept is clear since Article 55 of The Hague Regulations which supports a specific concept for the theory "enjoy the fruits". Anyhow, Israel's explanation for this idea grants Israel a motivation to prolong the occupation to exploit the Palestinian natural resources for its favor ${ }^{25}$.

The Israeli practices endanger the Palestinians right of permanent sovereignty over their natural resources and enables Israel from exploiting these resources 'indefinitely'. It is a great challenge for the Palestinians to practice their right to self-determination over their lands.

In 2015, the United Nations Special Rapporteur on human rights in the occupied Palestinian Territories, Michael Lynk, noted that Israel's mining and exploitation the Palestinians' natural resources prevents Palestinians from enjoying their natural resources and their right to self-development, and this constitutes a direct violation of Israel's legal responsibility as an occupying power, adding that the natural wealth and minerals from the Dead Sea are exploited by Israel for its own benefit ${ }^{26}$.

\section{The Israeli responsibility as an occupier towards the Palestinian occupied lands}

Article 43 of the Hague Regulations stipulates that: It is the responsibility of the legitimate power having in fact passed into the hands of the occupant, to take all the measures to restore, and ensure, public order and safety, while respecting, unless absolutely prevented, the laws in force in the country.

\footnotetext{
${ }^{23}$ Levenson,C:" New Israeli-Palestinian Land Dispute rises as Dead Sea Water Drop", Haaretz (10 November 2011).

${ }^{24}$ Richard and Issac: Water Resource allocations in the Occupied Palestinian Territory: Responding to Israeli claims, Ma'an News Agency (10 November 2013).

${ }^{25}$ Scobbie, I: Natural Resources and Belligerent Occupation: Perspectives from IHL and human rights law, Oxford University Press, $2009 . P .77$. ${ }^{26}$ Corporate complicity in violations of international law in Palestine. Badeel Magazine 2015. 
Article 43 of the Hague Regulations also asks the occupier to take all the possible procedures to ensure the public order and safety and requires the occupier to respect the laws and administrative rules in force in the occupied land ${ }^{27}$.

The Israeli occupation is considered a temporary case, so Israel does not have the legal sovereignty over the Palestinian territories and consequently its natural resources. The complete sovereign rights over the Palestinian Territories are normally for the Palestinians. According to the law of occupation, Israel as an occupier acts only as the de facto administrator of the Palestinian Territories; it should preserve the sovereign rights of the occupied Palestinians, and keep Palestinians and their lands from mining, exploitation and depletion by Israel.

IHL rules impose certain limitations on Israel, the occupier's power's use of the Palestinians' properties and natural resources found in the Palestinian territories, thereby stopping it from exploiting the wealth of Palestine to promote and support its own economy.

The procedures which are adopted by Israel in the Palestinian territories must meet two essential factors: the implementation of its own military needs and respect for the favors of the Palestinian inhabitants. It is prohibited for Israel to promote its own economy. Israel is permitted to take certain steps or measures to face dangers which threat the security of its employees and special properties located in Palestine. Anyhow, these military needs must not affect and overcome the essential needs the Palestinians require ${ }^{28}$.

The state is responsible for every act or omission that goes against its international commitments, regardless the authority that exercised it, legislative, executive, or judicial ${ }^{29}$. Therefore, this country must make reparation for the damages arising from the destruction of natural resources, which is a violation of the rules of international humanitarian law ${ }^{30}$.

\section{Conclusion}

The United Nations' resolutions consistently affirm the right of the Palestinians to sovereignty over their natural resources and control over their land, and the applicability of international human rights and humanitarian law, particularly the Fourth Geneva Convention of 1949, to the occupied Palestinian Territories, including East Jerusalem. All measures taken by Israel to exploit the resources and other economic activities in the occupied territories are illegal. Israel, as an occupying power, must stop these illegal measures, and the Palestinians have the right to recover their wealth and resources, and Israel must compensate them fully for the illegal exploitation and depletion of those resources.

According to international law, sovereignty over the territory is linked to wealth and natural resources, and they are subject to state ownership ${ }^{31}$.

The Palestinian human rights institutions, Al-Haq, Al-Mezan Center for Human Rights, and the Palestinian Center for Human Rights submitted a 500-page file to the Prosecutor of the International Criminal Court, on 26/October/2018 against Israeli officials, who committed war crimes of destruction, looting and confiscation of property as a part of a comprehensive and systematic policy of annexation, exercise of sovereignty and ensuring Israeli control through settlement expansion to seize and destroy Palestinian resources, which constitutes a violation of Israel's obligations to international law in relation to the occupied territories, and has serious economic and social repercussions on Palestinian communities, in particular, a violation of the right of the Palestinians to self-determination ${ }^{32}$.

And recently, the General Assembly's Economic and Financial Committee (Second Committee) has adopted a resolution on Thursday, the $19^{\text {th }}$ of November that affirms the Palestinian sovereignty over their natural resources, including lands, water, and energy resources.

The research concluded to certain results and recommendation. The most important are the following 33 .

${ }^{27}$ Article 43 of the Hague Regulations. Benevistti, E: The International Law of Occupation, Princiton University Press, $1993 . P 28$.

${ }^{28}$ The occupying power is not entitled to interfere in the economic activity of the territory under its control, unless such interference meets its own military or security needs; defrays the expenses involved in the occupation; or protects the interest or well-being of the inhabitants of the occupied territory. Cassese, A: International Law and the Administration of the Occupied Territories, Clarendon Press, Oxford 1992. P. 422.

${ }^{29}$ Firas Zuheir alhuseiny: International protection of water resources and water installations during armed conflict. Al-halabi legal publishes, Beirut 2009. P. 49.

30 UN DOC. 4/L. 602/rev 1, 26 July 2001 chereinafter I/C Articles On State Responsibility.

31 Ahmed Saeed Agha, Protection of Natural Resources According to the Provisions of Public International Law, the Palestinian Case as a Model," Journal of the Arab American University for Research. Volume 3, 2017, p. 42.

32 The Palestinian Center for Human Rights, human rights organizations submit a file to the Prosecutor of the International Criminal Court, to investigate and prosecute acts of looting and the appropriation and destruction of Palestinian natural resources. The web page: https://pchrgaza.org/ar.:

33 The UN official Website. the 19th of November 2021. 
Results

- Israel captured the Palestinian Territories, mainly to mine and to exploit its natural resources (the underground water, the land, and the Dead Sea). The Jewish state aims to promote and support its own economy. This action is contrary to the rules of IHL.

- No doubt that mining and extracting natural resources in Palestine by Israel for economic benefits amounts to the war crime of pillage, so the Israeli officials shoulder the legal responsibility for committing these types of crimes.

- Building up the Discrimination and Separation Wall, housing the Israeli inhabitants in the Palestinian Lands, and exploiting the natural resources is considered a grave violation to the rules of Public International and IHL.

- Israel encourages its own civilians to build settlements in the Palestinian Territories.

- The Jewish State deliberately and illegally damages the Palestinian agricultural land used for agriculture, water springs, and the Dead Sea natural resources.

- The right of the Palestinians to mine and keep their natural resources is legitimate. Israel is bound to guarantee this right.

- The Palestinians fell victims as a result of the environmental injustice resulted from a legal lacuna implied in Oslo Agreements. The proposed autonomy for the Palestinians did not actually include a reasonable access to their natural resources which are completely exploited by Israel, the occupying power.

\section{Recommendations}

- Israel has to abandon its illegal mining and benefiting from the natural resources in Palestine, causing the injury to the inhabitants' properties, building up the Discrimination Wall, housing the Israeli civilians in the Palestinian Territories, and exploiting the Dead Sea natural resources. Israeli procedures and activities severely violate the rules of Public International Law, Human Rights law and IHL.

- Israel, as an occupying power, must stop Mekorot and Ahava companies from practicing their illegal activities in the Palestinian Territories. These companies are obliged to shoulder the legal effects for the violation of the IHL provisions.

- Israel must completely end its imposed restraints on access to, and utilize of the Palestinian natural water resources, which means, in one way or another the permanent sovereignty for the Palestinians over their natural resources in Palestine.

- The Palestinians should demand Israel for full compensation, since it has been systematically and unlawfully exploiting and damaging the Palestinian natural resources. It should demand the friendly countries, besides the UN for legal assistance to achieve this mission.

- The High Contracting Parties to the Geneva Conventions must do their best to urge Israel to guarantee and show full respect to the Geneva Conventions and abide by their obligations according to Common Article 1 under IHL.

- The UN members must take legal and practical steps to practice the necessary pressure on Israeli to stop its flagrant violations for human rights in Palestine, and not involved in any kind of cooperation with Israel, commercially or military.

- The State of Palestine may request the United Nations to activate Chapter 7 of the UN Charter, which gives the authority to the Security Council to use force against Israel, the aggressor country to implement the United Nations resolutions related to the Palestine case.

\section{Sources and References \\ First: Sources}

1. Geneva Conventions

2. UN resolutions

\section{Second: References}

\section{Books:}

1. Agha, Ahmed Saeed (2017). Protection of Natural Resources According to the Provisions of Public International Law, the Palestinian Case as a Model. Journal of the Arab American University for Research, 3.

2. Alamlah, J.T. (2014). The Israeli Violations for the Palestinian Rights in Land and Housing. Society of Arab Studies.

3. Benevistti, E. (1993). The International Law of Occupation. Princiton University Press.

4. Caffery, S. (2007). The Law of International Watercourses. Oxford University Press.

5. Cassese, A. (1992). International Law and the Administration of the Occupied Territories. Clarendon Press. 
6. Dinstein, y. (2004). The Conduct of Hostilities under the Law of International Armed Conflict. Cambridge University Press.

7. Dough Brooks (2000). Messiahs or Mercenaries? The Future of International Private Military Services. International Peacekeeping, 7(4): 129-144. https://doi.org/10.1080/13533310008413867

8. Gillard, E.C. (2007). Private Military Security Companies: The status of their staff and their obligations under IHL and the responsibilities of states in relation to their operations. Research published in a book (Private Military and Security Companies: Ethics, Policies and Civil Military Relations), First Edition.

9. Alhuseiny, Firas Zuheir (2009). International protection of water resources and water installations during armed conflicts. Al-halabi legal publishes.

10. Abu Alkair, A.M. (2008). Private Military and Security Firms, (Legal Study). Itrak Company.

11. Koek, E. (2013). Water for one People Only. Alhaq.

12. Levenson, C. (2011). New Israeli-Palestinian Land Dispute rises as Dead Sea Water Drop. Haaretz.

13. Mansoor, Suliemam (2014). The Zionist Policy towards Arab Water. The faculty of Law and Political Science, the second issue.

14. Lucia, V. (2015). Enviromental Injustice in Occupied Palestinian Territories. Alhaq Foundation.

15. Nicoleti, C. (2012). Pillage of the Dead Sea. Alhaq Foundation.

16. Alqasem, A. (2009). The Wall of Ideology. Dar Alfikr.

17. Richard \& Issac (2013). Water Resource allocations in the Occupied Palestinian Territory: Responding to Israeli claims. Ma'an News Agency.

18. Scobbie, I. (2009). Natural Resources and Belligerent Occupation: Perspectives from IHL and human rights law. Oxford University Press.

19. Singer, P.W. (2004). The Private Military Industry and Iraq.

20. Takahanshi, Y. (2009). The Law of Occupation. Martinus Publisher.

21. Yaqin, S. (2015). The Israeli Apartheid Wall. Arab center Studies.

\section{Third: Internet References and Reports}

1. Report of the United Nations Conference on Environment and Development (Reo de Janiero, 13-14 June 1992), Annex 1 'Reo Declaration on Environment and Development', UN Doc. Vol. 1, 1992.

2. Taylor, k: Who profits; The Israeli Occupation Industry, Ahava: Tracking the Trade of Settlements Products, (May 2012). http://www.privco-com/private-company/ahava-dead-sea-products.

3. The advisory Opinion of the ICJ. (United Nations official website).

4. UN DOC. 4/L. 602/rev 1, 26 July 2001 cherein after I/C Articles on State Responsibility

5. West Bank Settlements: Facts and Figures (2009). http. //Peace now.org.il.org. /node/297. 